\section{SHORTAGE OF SCIENTIFIC TEXT- BOOKS IN CAMBRIDGE}

\begin{abstract}
A SURVEY carried out in Cambridge during MarchApril among teaching staffs and booksellers shows that nearly half of the scientific books the average student is recommended to buy are not available for him to buy new. It also shows that American books cover 33 per cent of all books students are recommended to buy, as opposed to 10 per cent before the War.
\end{abstract}

Teachers from twelve scientific departments of the University supplied lists of recommended text-books and also indicated the annual number of students likely to require each book. 145 titles were listed in all, 97 being of British origin and 48 American. Some books were, of course, alternatives to others, but the 145 titles covered 128 separate 'topics'.

The availabilities of American and British books depend upon different factors and were, therefore, estimated by different methods. Booksellers stated that the number of American books demanded has approximately doubled since 1939, whereas their average price has risen by about 50 per cent. Thus the current demand is about 300 per cent by value of the pre-war demand. Since permitted imports are now 200 per cent by value of pre-war imports, it is estimated that approximately two-thirds or 67 per cent of the American books now required are available. In other words, a student requiring an American book has, on the average, a two-thirds chance of obtaining it; a particular student may, of course, do better than this, either by good luck or by his own efforts. The above estimate neglects the possibility that an American book is out of print. The number of such books is small, and, in any event, should affect neither the total imports of American books nor the average availability in Great Britain. Also, no account is taken of books imported as single copies direct from the United States to the British purchaser; this factor is not thought to be important so far as students are concerned.

With the co-operation of booksellers, the British books were classified as : (1) available for immediate sale; (2) reprinting or new edition in preparation; (3) out of print. The data thus obtained referred to a particular date (early April 1948); but it seems probable that the percentage availability of a large sample of books at any one time will give a fair measure of their average availability over a period, individual fluctuations cancelling one another out. In fact, the availability found for the particular date agreed with the booksellers' own independent impression of the general position. Further, unless major changes in policy occur, of which there is no indication, the estimates should also hold for the near future. The student may, of course, be able to get second-hand copies, but this factor also does not seem to be of major importance, especially since students now finishing their courses are stated to have a greater tendency than formerly to keep their books. The data obtained refer to a wide range of subjects, but analysis showed that the position is not significantly different as between (1) physical and biological sciences, (2) books required by a large number of students (more than fifty copies a year) and those required by fewer.

Of the 128 'topics' analysed, 55 were available in British books. 48 were unavailable in British books and no American alternative was mentioned (of the
48 'topics', 33 books were reprinting and 15 were out of print). For the remaining 25 'topics', only American books were in print and it was assumed that 17 of these were actually available and 8 not available (that is, a 67 per cent availability as stated in a previous paragraph). Hence only 72 (55 plus 17) out of the 128 'topics' were available in any form, that is, 56 per cent.

As stated above, 97 of the 145 titles were British, and 56 per cent of these were available. It will be noted that this compares unfavourably with the percentage availability of American books (67 per cent). It is of further interest that about 50 per cent of the American books were listed as alternatives to British books, and about 20 per cent of the British books were given with American alternatives. Both booksellers and teachers confirmed that the demand for American books has considerably increased since before the War and now represents about 33 per cent of the total demand, as opposed to 10 per cent before the War.

The survey comments that the advantage that American books have over their approximate British alternatives is due primarily to the paper shortage and other obstacles to British book production, coupled with the lack of priority as to subject-matter in the allocation of paper to British publishers. This lack of discrimination at home stands in marked contrast to the complete discrimination in favour of learned, scientific and technical books when imported from abroad. The supplies of British text-books are affected both by low production and high export. Out of a total value of more than $£ 30$ million for books of all types produced in Britain in 1947, 24.5 per cent was exported (The Bookseller, March 20, 1948). The proportion of British book production (all types) exported was as high as 35 per cent in 1940 and 29 per cent in 1941 (The Bookseller, March 20, 1948). The much-enhanced position of American scientific books in the British market dates from that time. It has not been seriously affected by the short period in which imports were cut to 100 per cent of pre-war value. American publishers are continuing to press their advantage, arising from Britain's production difficulties and her need to export.

Many of the newer American books are, of course, invaluable, and no British alternative exists. This is especially true of up-to-date scientific and technological works of reference. In this respect American books have an advantage over British ones, quite apart from Britain's immediate production difficulties and need to export. In great part, of course, the advantage arises from the larger scale of American industrial and scientific activity generally, and hence the greater number and variety of specially qualified authors. Nevertheless, there are other, less unavoidable, reasons for the relative paucity of new British advanced works. Delays in publication put British books at a disadvantage by increasing the chances that a new American book will have arrived and satisfied the demand in a subject before an already. written British book on that subject appears. Furthermore, inquiries in Cambridge indicate that new British works are not being written in numbers commensurate with our supply of qualified authors. An important deterrent mentioned was lack of time and (not so important) lack of financial inducement. Increased teaching pressure leaves little time for the writing of new books and makes it difficult for those who fell behind in their reading while on war-work to catch up again. The direct financial inducement to write 
advanced scientific works was never great; but to-day it is smaller than ever. Publishers try to share out their limited paper among the most needed titles, and the consequent small impressions mean correspondingly small royalties. The survey suggests that official encouragement should be given to the writing of new books by British specialists.

It is stated that a good case can be made out for the large percentage of book production which goes to export. It is emphasized, however, that this trade and, even more important, this reputation, are in danger unless our total volume of 'learned, scientific and technical' book production is increased both in number of copies of existing standard works and in new titles. The value of American exports of books (all types) to all countries had not in 1947 quite equalled Britain's; but 1947 was the year in which the import of America's books was artificially restricted by two of her best customers, Britain and
Australia. In spite of that, American exports rose more steeply than our own. With British import restrictions relieved, American exports may be expected to surpass Britain's. Moreover, America can, as Britain cannot, increase the exported fraction of her total production without serious consequences for the home consumer. America's exported fraction was only 7 per cent of the total (in 1946) as against Britain's 25 per cent. The conclusion is drawn that it is essential that British scientific book production should be increased by giving priority in material allocation to the publication of such books, so that both the home and export markets may be better supplied.

This survey was carried out by the Cambridge Branch of the Association of Scientific Workers, and copies of the complete survey are available from the Head Office of the Association (15 Half Moon Street, Piccadilly, London, W.1).
R. INNES

\section{NEWS and VIEWS}

Physiology at the London Hospital Medical College: Dr. John L. D'Silva

Dr. JoHn L. D'Sinva, reader in physiology at St. Bartholomew's Hospital Medical College, who has been appointed to the chair of physiology at the London Hospital Medical College, was born and educated in southern India. He graduated with first-class honours in chemistry at King's College, London, in 1929, and remained there for a further three years doing research on the chemistry of disulphides. In 1932 he went over to physiology, still at King's College, carrying out investigations on the effect of adrenaline on the metabolism of potassium. After a short period with Messrs. British Drug Houses, Ltd., spent on research into the molecular distillation of fish oils in connexion with the study of vitamin $A$, he went in 1936 to St. Bartholomew's Hospital Medical College, where he was demonstrator in physiology and in biochemistry, and continued his work on the metabolism of adrenaline and potassium. He was awarded the degree of D.Sc. for his published work. During the Second World War, Dr. D'Silva qualified as a medical practitioner and also continued teaching. After work at St. Bartholomew's Hospital, in 1944 Dr. D'Silva was appointed to the Medical College again and has remained there since, lecturing and carrying out research on the physiology of the visual process.

\section{Jöns Jakob Berzelius (1779-1848)}

WHEN he died a century ago on August 7, 1848, Berzelius was not only the most famous chemist of the world, but also the autocrat of the world of chemistry. The son of a schoolmaster, he was born near Linköping on August 29, 1779. After studying medicine and chemistry at Uppsala, at the age of twenty-three he was appointed assistant professor of botany and pharmacy at Stockholm, and full professor in 1807. During 1815-32 he held the chair of chemistry in the Caroline MedicoChirurgical Institution. In 1818 he became perpetual secretary of the Stockholm Academy of Seiences, and received a title of nobility, with permission to retain his name. Seventeen years later, on the occasion of his marriage, he was made Freiherr. Berzelius spent some ten years determining with great accuracy the atomic and molecular weights of more than two thousand chemical substances; he isolated selenium, thorium, silicon, titanium and zirconium, and also prepared and examined many organic compounds. He devised the present system of chemical symbols. His "Lehrbuch der Chemie", begun in 1808, went through five editions and, in various translations, spread his fame over Europe. His dualistic electrochemical theory exerted a profound influence on the progress of chemistry. Though Berzelius worked in the simplest of laboratories, his reputation attracted students from many countries. In his hands the blow-pipe became the symbol of qualitative dry analysis. Distinguished in appearance, inclined to be portly, neat in attire and habits, cordial and unassuming, Berzelius was vigorous in body and mind, though essentially conservative in his outlook. Of his characteristic sayings the following may serve as a sample : "The devil may write text-books of chemistry, for every few years the whole thing changes".

\section{Australian Journal of Scientific Research}

THE Australian Council for Scientific and Indus. trial Research, in collaboration with the Australian National Research Council, has decided to take responsibility for the establishment in Australia of a new seientific journal, the Australian Journal of Scientific Research, as a medium for the publication of research papers of outstanding merit. This journal is open to receive contributions from research workers, irrespective of country or of the organisation to which they are attached. Dr. N. S. Noble has been appointed as editor of the new journal. Editorial policy will be determined by an editorial board under the chairmanship of the editor and comprising as members: Prof. W. J. Dakin (Department of Zoology, University of Sydney), Prof. E. J. Hartung (Department of Chemistry, University of Melbourne), Prof. L. H. Martin (Department of Physies, University of Melbourne), and Prof. J. G. Wood (Department of Botany, University of Adelaide). The Board aims at achieving a high standard of quality in papers accepted and a strict refereeing system has been instituted. The Journal will be printed in two series: Series A (Physical Sciences) and Series B (Biological Sciences). Initially each series will be issued quarterly and will cost $30 s$. a year. 